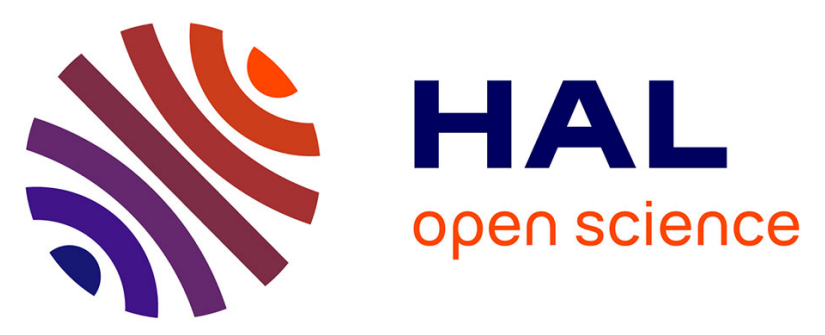

\title{
Nodularin induces oxidative stress in the Baltic Sea brown alga (Phaeophyceae)
}

Stephan Pflugmacher, Miikka Olin, Harri Kankaanpää

\section{To cite this version:}

Stephan Pflugmacher, Miikka Olin, Harri Kankaanpää. Nodularin induces oxidative stress in the Baltic Sea brown alga (Phaeophyceae). Marine Environmental Research, 2007, 64 (2), pp.149. 10.1016/j.marenvres.2006.12.011 . hal-00501900

\section{HAL Id: hal-00501900 https://hal.science/hal-00501900}

Submitted on 13 Jul 2010

HAL is a multi-disciplinary open access archive for the deposit and dissemination of scientific research documents, whether they are published or not. The documents may come from teaching and research institutions in France or abroad, or from public or private research centers.
L'archive ouverte pluridisciplinaire $\mathbf{H A L}$, est destinée au dépôt et à la diffusion de documents scientifiques de niveau recherche, publiés ou non, émanant des établissements d'enseignement et de recherche français ou étrangers, des laboratoires publics ou privés. 


\section{Accepted Manuscript}

Nodularin induces oxidative stress in the Baltic Sea brown alga Fucus vesiculosus (Phaeophyceae)

Stephan Pflugmacher, Miikka Olin, Harri Kankaanpä ä

PII:

S0141-1136(07)00007-4

DOI:

10.1016/j.marenvres.2006.12.011

Reference:

MERE 3092

To appear in:

Marine Environmental Research

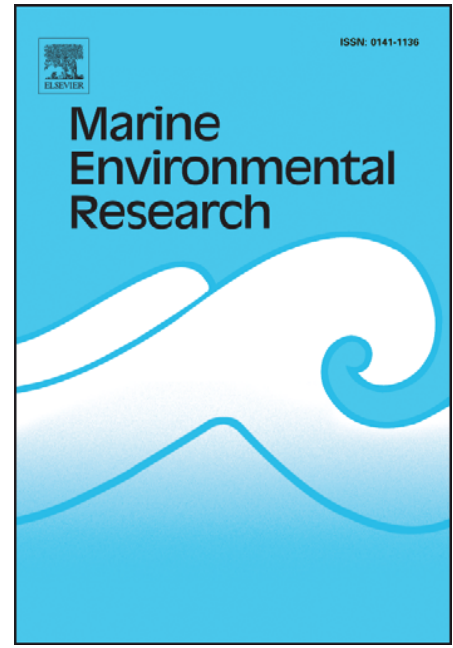

Received Date: $\quad 18$ May 2006

Revised Date: $\quad 19$ December 2006

Accepted Date: $\quad 20$ December 2006

Please cite this article as: Pflugmacher, S., Olin, M., Kankaanpä ä, H., Nodularin induces oxidative stress in the Baltic Sea brown alga Fucus vesiculosus (Phaeophyceae), Marine Environmental Research (2007), doi: 10.1016/ j.marenvres.2006.12.011

This is a PDF file of an unedited manuscript that has been accepted for publication. As a service to our customers we are providing this early version of the manuscript. The manuscript will undergo copyediting, typesetting, and review of the resulting proof before it is published in its final form. Please note that during the production process errors may be discovered which could affect the content, and all legal disclaimers that apply to the journal pertain. 
Mscript for Marine Environmental Research revised version !

\section{Nodularin induces oxidative stress in the Baltic Sea brown alga Fucus vesiculosus (Phaeophyceae)}

Stephan Pflugmacher ${ }^{1)}$, Miikka Olin ${ }^{2)}$, Harri Kankaanpää ${ }^{2)}$

${ }^{1}$ Leibniz Institute of Freshwater Ecology and Inland Fisheries, Biochemical Regulation, Müggelseedamm 301, 12587 Berlin, Germany

${ }^{2}$ Finnish Institute of Marine Research, PO Box 2, FIN-00561 Helsinki, Finland

\section{Corresponding author:}

PD Dr. Stephan Pflugmacher

Leibniz Institute of Freshwater Ecology and Inland Fisheries

AG Biochemical Regulation

Müggelseedamm 301

12587 Berlin

phone: 0049-30-64181-639

fax: 0049-30-64181-682

email: pflugmacher@IGB-Berlin.de 


\title{
ACCEPTED MANUSCRIPT
}

\begin{abstract}
In the Baltic Sea regular, intensive cyanobacterial blooms rich in the cyanobacterium Nodularia spumigena occur during the summer season. Nodularia spumigena is known to produce the cyclic pentapeptide nodularin (NOD) in high concentrations. Marine macroalgae, together with sea-grass meadows, are an extremely important habitat for life in the sea. In addition to this, the decaying macroalgae substantially contribute to the substrate for the microbial loop in coastal food webs. Uptake of nodularin into the brown macroalga Fucus vesiculosus was assessed using an ELISA technique resulting in an uptake of up to $45.1 \mu \mathrm{g}$ $\mathrm{kg}^{-1}$ fresh weight (fw). Nodularin was also detected in the reproductive part of the algae (receptacle) at $14.1 \mu \mathrm{g} \mathrm{kg}^{-1} \mathrm{fw}$. The induction of oxidative stress in $F$. vesiculosus, after exposure to NOD, was also shown by monitoring cellular damage as changes in lipid peroxidation and the activation of antioxidative defence systems (antioxidative capacity, superoxide dismutase and soluble glutathione S-transferase).
\end{abstract}




\section{Introduction}

During the past one hundred years the phosphorous load into the Baltic Sea has increased by about eight-fold and the nitrogen load about four-fold (Larsson et al., 1985). As a consequence of this, the pelagic primary production has increased by an estimated $50 \%$ (Elmgren, 1989) and sedimentation of organic carbon five to ten-fold (Jonsson \& Carman 1994). In the northern Baltic Sea regular, intensive cyanobacterial blooms rich in the cyanobacterium Nodularia spumigena occur during the summer season (Sivonen et al., 1989). Nodularia spumigena is known to produce the cyclic pentapeptide hepatotoxin nodularin (NOD) in high concentrations (Sivonen et al., 1989). The most common NOD is NOD-R, or cyclo(-D-erythro- $\beta$-methylAsp(iso)-L-Arg-Adda-D-Glu(iso)-2-(methylamino)-2-(Z)-

dehydrobutyric acid), where Adda stands for 3-amino-9-methoxy-2,6,8-trimethyl-10phenyldeca-4(E),6(E)-dienoic acid (Carmichael et al., 1988). The concentration of NOD in the Baltic Sea has been shown to range from $0.5 \mu \mathrm{g} \mathrm{L}^{-1}$ to $25.8 \mu \mathrm{g} \mathrm{L}^{-1}$ with a maximum cellbound concentration of $18.1 \mathrm{mg} \mathrm{kg}^{-1}$ (Kononen et al., 1993; Kankaanpää et al., 2001; Mazur and Plinski, 2003).

Several cases of animal poisonings in the southern Baltic Sea have been reported (Edler et al., 1985; Nehring 1993). Changes in liver histopathology have also been observed in trout exposed in vivo with Nodularia cells containing NOD (Kankaanpää et al. 2002). Other recent studies have indicated that NOD can accumulate into blue mussels (Mytilus edulis; Sipiä et al., 2001a) and some Baltic fish species, e.g. flounder (Platichthys flesus; Kankaanpää et al. 2002), Atlantic cod (Gadus morhua; Sipiä et al., 2001b) and the three-spined stickleback (Gasterosteus aculeatus; Kankaanpää et al., 2001). One feature of rocky seashores in the Baltic Sea is the growth of macroalgae belonging to three different phyla: Rhodophyta (red algae), Phaeophyta (brown algae) and Chlorophyta (green algae). These algae, together with sea-grass meadows, are extremely important for life in the sea. Macroalgae are not to a great extent utilised by primary consumers as a food source, but for numerous smaller animals, 
such as isopods (especially Idotea baltica), benthic isopods (e.g. Saduria entomon), blue mussels, crustaceans, scallops, starfish and lobsters they do provide shelter. Several of the economically most important fish species, herring or pollock, are entirely dependent on the macroalgae zones in their early life stages. Macroalgae also increase the available substrate for benthic microalgae, which in turn are the main food for small herbivores. In addition to this, the decaying macroalgae are substantially contributing to the substrate for the microbial loop in coastal food webs (Mann 1982, Lüning 1990). It has been shown that cyanobacterial toxins can promote oxidative stress in freshwater macrophytes (Pflugmacher, 2004). To prevent cellular damage caused by reactive oxygen species (ROS), cells have an elaborate system involving antioxidative enzymes which include superoxide dismutase (SOD), glutathione peroxidase (GPx), ascorbate peroxidase (APx), catalase (CAT) and glutathione reductase (GR). Superoxide Dismutase (SOD) catalyzes the dismutation (reduction) of superoxide anions into oxygen and hydrogen peroxide. Hydrogen peroxide is reduced by CAT, GPx or APx to water, the latter using ascorbate as an electron donor. Glutathione reductase is part of an oxido-reduction cycle involving glutathione and ascorbate (Foyer \& Halliwell, 1976; Smith et al., 1990). Glutathione reductase catalyses the reduction of glutathione disulfide (GSSG) in an NADPH-dependent reaction and therefore plays a pivotal role in protection against oxidative damage and the adjustment processes of metabolic pathways.

Marine macroalgae, many of which play an important role in the marine coastal ecosystem, have so far been overlooked in relation to cyanobacterial toxins. The aim of this study was to examine any effects of a NOD-containing crude cell extract of $N$. spumigena on the most abundant Baltic Sea brown algae, the bladder wrack Fucus vesiculosus and in particular the promotion of oxidative stress and the distribution of NOD throughout the plant. Reactive oxygen metabolism plays a major role in seaweed with regard to stress tolerance (Collen \& Davison, 1997, 1999a, b) and stress factors such as cyanobacterial toxins may be able to 
promote oxidative stress which in turn may have a long-term ecological significance on the ecosystem of the Baltic Sea as a whole.

\section{Material and Methods}

\section{Algal material}

Fucus vesiculosus was collected from a rocky bottom (5-10 m depth) by SCUBA south of the Helsinki University Zoological station in Tvärminne (Hanko Peninsula, SW Finland) in May 2005. The algae, attached to its original rock material, were cultivated and acclimatised in circulating natural Baltic Sea water (pumped from the vicinity of the station through filters) under laboratory conditions $\left(12 \mathrm{~h} / 12 \mathrm{~h}\right.$ diurnal cycle, $+10^{\circ} \mathrm{C}$, salinity of 6 , ambient dim light) for two months prior to the experiments. Prior to the experiments the algae were detached from the rock material by carefully cutting the holdfast from the rock.

\section{Preparation of a nodularin-containing crude cell extract}

In order to mimic the natural dissolution of the chemical constituents of Nodularia spumigena into Baltic Sea water, a crude cell extract was prepared. One gram of freeze-dried $N$. spumigena, cells collected in July 2003, was extracted with $10.0 \mathrm{ml}$ of filtered Baltic Sea water (salinity 6). The extraction was performed over 15 minutes using an ultrasonic bath (Branson 3200). After ultrasonication, the mixture was centrifuged at $10000 \mathrm{x} g$ for $10 \mathrm{~min}$, and the supernatant collected. The extract obtained contained $150 \mathrm{mg} \mathrm{NOD} \mathrm{L}^{-1}$ and was stored at $+4{ }^{\circ} \mathrm{C}$ until required.

\section{Exposure of $F$. vesiculosus to the crude extract}

Fucus vesiculosus, maintained in Baltic Sea water were exposed to a nodularin-containing crude cell extract by producing a solution (diluted with seawater of salinity 6 ) containing $1 \mu \mathrm{g}$ $\mathrm{L}^{-1} \mathrm{NOD}$ in a $15 \mathrm{~L}$ tank. Control plants were kept in a $40 \mathrm{~L}$ tank. During the $48-\mathrm{h}$ 
experimental exposure water circulation was stopped (static exposure). Triplicate algal samples were taken (whole thallus) for analyses of oxidative stress (lipid peroxidation, ROS) and GST induction from both the exposed and control tank at 0, 0.5, 1, 4, 6, 12, 24 and 48 hours from the start of exposure. The concentration of NOD in the exposure medium was measured by ELISA (EP 022; EnviroLogix Inc, Portland, USA) according to the manufacturers' instructions, prior to exposure and at the end of the exposure period to control possible toxin degradation. Material for distribution analysis of total extractable NOD in the holdfast, stripes, blades and the gametangial part (receptacle) were collected at $48 \mathrm{~h}$ only.

The sectioned algal material collected at the end of the experiment was first gently washed with $75 \%(\mathrm{v} / \mathrm{v})$ methanol to remove any extracellular NOD from the surface of the plant. The sections were wrapped in aluminium foil, snap frozen in liquid nitrogen, placed on dry ice and stored at $-78^{\circ} \mathrm{C}$ prior to extraction.

\section{Extraction of $F$. vesiculosus for toxin analysis}

Exactly $1.0 \mathrm{~g}$ of fresh weight (fw) of whole algae was frozen in liquid nitrogen, ground to a fine powder and NOD extracted according to Pflugmacher (2004) using $10 \mathrm{ml}$ of $70 \%(\mathrm{v} / \mathrm{v})$ methanol for the first extraction. These samples were shaken for $4 \mathrm{~h}$ at room temperature, centrifuged at $5000 \times \mathrm{g}$ for $10 \mathrm{~min}$ and the supernatant removed and stored at $4{ }^{\circ} \mathrm{C}$. The algal material (pellet) was further extracted with $100 \%$ methanol as previous. The supernatants were combined and evaporated to dryness under a constant flow of nitrogen and gentle heating at $30^{\circ} \mathrm{C}$ and finally redissolved in $1.0 \mathrm{ml}$ of $70 \%(\mathrm{v} / \mathrm{v})$ methanol prior to analysis.

\section{Total extractable hepatotoxin (TEH) analysis using ELISA}

The extracts in $70 \%$ methanol were further diluted with Milli-Q water to produce dilutions of 1:10, 1:100 and 1:1000. The dilutions were analysed in triplicate using EnviroLogix EP 022 (Portland, Maine, USA) ELISA plates according to the manufacturer's instructions. Results 
are based on those dilutions falling within the range of calibration range $(0.25-2.0 \mu \mathrm{g}$ NOD /L) used.

\section{Lipid peroxidation}

Exactly $1.0 \mathrm{~g}$ of algae was suspended in $2 \mathrm{~mL} 0.1 \mathrm{M}$ phosphate buffer (pH 7.4), centrifuged at $13.500 \times \mathrm{g}$ for $5 \mathrm{~min}$ and the pellet was homogenised $1 \mathrm{~mL} 20 \mathrm{mM}$ phosphate buffer (pH 7.4). $10 \mu \mathrm{L}$ of butylated hydroxytoluene (BHT) (Merck, Darmstadt, Germany) was added to prevent sample oxidation. The precipitate was removed by centrifugation $3000 \mathrm{x} g$ at $4{ }^{\circ} \mathrm{C}$ for 10 min. The supernatant was used for the lipid peroxidation assay and for protein determination by Bradford (1976) method. Lipid peroxidation (LPO) in F. vesiculosus was measured according to Botsoglou et al. (1994) as amount of malondialdehyde (MDA) and 4hydroxynonenal (4-HNE) (Merck, Darmstadt, Germany), which are end products of unstable and decomposing lipid peroxides. The reaction of the chromogenic reagent N-methyl-2phenylindole with MDA gives a stable chromophore with maximum absorbance at $586 \mathrm{~nm}$. A calibration curve was made using MDA. For the analysis of MDA, $200 \mu \mathrm{L}$ of the extract was used and $600 \mu \mathrm{L}$ of N-5 methyl-2-phenylindole in acetonitrile was added and gently mixed. A volume of $150 \mu \mathrm{L}$ of $12 \mathrm{M} \mathrm{HCl}$ was added, mixed again and incubated at $45{ }^{\circ} \mathrm{C}$ for $1 \mathrm{~h}$. Samples were centrifuged at $15.000 \mathrm{x} g$ for $10 \mathrm{~min}$ and the clear supernatant was transferred into a plastic cuvette for measurement. For the analyses of MDA and 4-HNE $200 \mu \mathrm{L}$ of the sample was mixed with $150 \mu \mathrm{L}$ of methane sulfonic acid (MSA) and incubated at $45{ }^{\circ} \mathrm{C}$ for 1h. Samples were cooled down and centrifuged at $15.000 \times \mathrm{g}$ for $10 \mathrm{~min}$ and the clear supernatant was transferred into a plastic cuvette for measurement at $586 \mathrm{~nm}$. 


\section{Total antioxidant capacity}

This assay was performed according to the method of Miller et al. (1993) and relies on the ability of antioxidants in the sample to inhibit the oxidation of $2,2^{\prime}$-azino-di-[3-ethylbenzthiazoline sulphonate] (ABTS) by metmyoglobin. The amount of oxidized ABTS is monitored at $600 \mathrm{~nm}$ with the absorbance of ABTS at $600 \mathrm{~nm}$ proportional to the concentration of antioxidants in the sample. The assay is linear for antioxidant levels less than $2.5 \mathrm{mM}$.

\section{Algal preparation for enzyme assays}

An algal extract was prepared according to Pflugmacher et al. (1999) with minor modifications, listed below. A total of $5 \mathrm{~g}$ wet weight of algae was used in three replicates for enzyme isolation. The algae were ground in liquid nitrogen to a fine powder, transferred into $0.1 \mathrm{M}$ sodium phosphate buffer ( $\mathrm{pH}$ 6.5) containing $14 \mathrm{mM}$-dithioerythritol (SIGMA) and 5 mM EDTA (SIGMA) and homogenized on ice using a glass homogenizer on ice. The resulting slurry was shaken for $30 \mathrm{~min}$ and centrifuged at $5000 \mathrm{x} \mathrm{g}$ for $5 \mathrm{~min}$. Soluble proteins in the supernatant were concentrated by ammonium sulphate precipitation using 35$80 \%$ saturation and centrifugation at $25000 \times \mathrm{g}$ for $30 \mathrm{~min}$. The pellet (soluble fraction) was resuspended in $20 \mathrm{mM}$ sodium phosphate buffer $(\mathrm{pH}$ 7.0) and desalted by gel filtration on NAP-10 columns (Amersham Pharmacia, Sweden). Protein determination was performed using the method of Bradford (1976).

\section{Measurement of SOD, CAT and GST activities}

Superoxide dismutase (SOD) (E.C. 1.15.1.1) activity was measured in the algal preparation according to Sun et al. (1988) using the xanthine/xanthine oxidase assay. Activity of catalase (CAT) was measured according to Aebi et al (1984). Activity of soluble (cytosolic) 
glutathione S-transferases (sGST) (E.C. 2.5.1.18) was determined using the standard model substrate 1-chloro-2,4-dinitrobenzene (CDNB) according to Habig et al. (1974) and 4hydroxynonenal according to Alin et al. (1985). Enzyme activities are given as nkat $\mathrm{mg}^{-1}$ protein (a katal is equivalent to the conversion rate of one mole of substrate per second).

\section{Statistical analysis}

One-way analysis of variances (ANOVA) and the Tukey's test at $p=0.05$ were used to test differences between exposures and control.

\section{Results}

After being exposed for $48 \mathrm{~h}$ to water containing an extract of $N$. spumigena, at $1 \mu \mathrm{g} 1^{-1} \mathrm{NOD}$, a total toxin uptake of $131 \mathrm{\mu g} \mathrm{kg}^{-1} \mathrm{fw}$ was detected in the thallus of $F$. vesiculosus. The highest uptake was measured in the holdfast with $45.1 \pm 4.2 \mu \mathrm{g} \mathrm{kg}^{-1}$ (fresh weight) fw, followed by the lower part of the stipe with $39.5 \pm 2.9 \mu \mathrm{g} \mathrm{kg}^{-1} \mathrm{fw}$. The stipe within the blades exhibited a NOD concentration of $20.8 \pm 4.5 \mu \mathrm{g} \mathrm{kg}^{-1} \mathrm{fw}$ and the blades itself $13.9 \pm 1.1 \mu \mathrm{g} \mathrm{kg}^{-}$

${ }^{1}$ fw. Nodularin was also detected in the gametangial, which is the reproductive part of these algae, at a concentration of $14.1 \pm 3.0 \mu \mathrm{g} \mathrm{kg}^{-1} \mathrm{fw}$.

One of the possible indicators of oxidative stress is lipid peroxidation (LPO) (Fig. 1), which was measured using the two metabolites malondialdehyde (MDA) and 4-hydroxynonenal (4HNE). 4-Hydroxynonenal was detectable after $1 \mathrm{~h}$ of exposure and MDA after $4 \mathrm{~h}$. The concentration of MDA was always 10-fold lower than the concentration of 4-HNE. The concentration of both metabolites was seen to increase until the end of the experiment at $48 \mathrm{~h}$.

The measurement of the total antioxidative status of $F$. vesiculosus revealed that, with time, the elevated concentration induced an 11-fold increase in the exposed algae when compared 
to controls. A significant increase of the total antioxidative status was observed after $6 \mathrm{~h}$ exposure to NOD (Fig. 2).

Activity of superoxide dismutase (SOD) (Fig. 3) was significantly elevated after 30 min of exposure of the algae to NOD and leveled-off over a further $4 \mathrm{~h}$. After $6 \mathrm{~h}$ of exposure, a second elevation occurred with a slight increase until the end of the experiment at $48 \mathrm{~h}$. As a whole, the SOD activity increased 3-fold during the course of the experiment.

Catalase (CAT) activity (Fig. 4) was significantly elevated after $1 \mathrm{~h}$ of exposure and continued to increase until $24 \mathrm{~h}$ attaining the highest activity of $28 \mu \mathrm{kat} \mathrm{mg}^{-1}$ protein. Between 24 and $48 \mathrm{~h}$ exposure the activity of CAT decreased 2-fold when compared to the $24 \mathrm{~h}$ value.

Glutathione S-transferase (GST) activity (Fig. 5A), when measured with CDNB, increased almost immediately on exposure with NOD with a constant elevation and a total 4.2-fold increase by $48 \mathrm{~h}$.

Based on the use of 4-HNE (one of the metabolites of lipid peroxidation) as substrate, the GST activity significantly elevated after $4 \mathrm{~h}$ of exposure reaching a maximum activity of 140 nkat $\mathrm{mg}^{-1}$ protein after $12 \mathrm{~h}$ (Fig. 5B). Apparently, the activity diminished towards the end of the experiment at $48 \mathrm{~h}$, although the decrease was statistically not significant.

\section{Discussion}

The use of a crude cell free extract made from a natural phytoplankton bloom sample was selected for its resemblance to naturally decaying bloom material. The concentration of NOD used in this study was environmentally relevant $\left(1.0 \mu \mathrm{g} \mathrm{l}^{-1}\right)$, when compared to concentrations detected in the pelagic Baltic Sea during cyanobacterial blooms (Kankaanpää et al., 2001). However, the cyanobacteria in the material will contain a complex mixture of several bioactive peptides which includes NOD (Sivonen et al., 1989). Thus, any responses observed in $F$. vesiculosus can not solely be attributed to NOD. 
Based on the exposure of $F$. vesiculosus to a NOD-containing cell free extract from $N$. spumigena bloom material, the uptake of NOD was evident. Nodularin concentration was determined using an ELISA, which, strictly speaking, is providing the total concentration of molecules able to bind to the antibodies of the ELISA plate (i.e. other hepatotoxins detected by the assay). It is however assumed that most of the total extractable hepatotoxins detected will consist of NOD as it is the dominant hepatotoxin found in the Baltic Sea.

Detectable concentrations of NOD were observed in different parts of $F$. vesiculosus, especially in the stem and basal parts. The total uptake of toxin by $F$. vesiculosus was $131 \mu \mathrm{g}$ $\mathrm{kg}^{-1} \mathrm{fw}$, which is in between the concentrations observed in other marine organisms such as herring (2.5-6.5 $\left.\mu \mathrm{g} \mathrm{kg}^{-1} \mathrm{dw}\right)$, stickleback (35-170 $\left.\mu \mathrm{g} \mathrm{kg}^{-1} \mathrm{dw}\right)$ and flounder liver (240-2500 $\mu \mathrm{g}$ $\mathrm{kg}^{-1} \mathrm{dw}$ ) (Kankaanpää et al., 2001; 2005, Karlsson et al., 2003).

An ecologically important effect potentially initiated by NOD in marine macroalgae can be the formation of reactive oxygen species (ROS) ie $\mathrm{O}_{2}{ }^{-}, \mathrm{O}_{2}{ }^{-}, \mathrm{H}_{2} \mathrm{O}_{2}$, and $\mathrm{HO}^{*}$. The promotion of oxidative stress by cyanobacterial toxins in the limnic macrophyte Ceratophyllum demersum has previously been demonstrated (Pflugmacher 2004). Cellular damage can include the breakdown of membrane integrity through peroxidation of lipids. Lipid peroxidation takes part in two distinct sequential reactions namely the initiation and the propagation of oxidation. In the first reaction, the formation of lipid hydroperoxides occurs, yielding the production of MDA. Secondly, propagation is an iron-catalysed breakdown of these hydroperoxides generating reactive intermediates, rapid formation of MDA and additional lipid hydroperoxides. The oxidation of polyunsaturated fatty acids in the membrane, particularly arachidonic acid and linoleic acid, leads to the formation of the major unsaturated aldehyde, 4-Hydroxynonenal (4-HNE). 4-HNE is a highly reactive compound known to have numerous cellular effects (Esterbauer et al., 1991). The concentration of 4-HNE in the cells is regulated by $\alpha$ class glutathione S-transferases (GST A4-4 and hGST5.8) which catalyse the formation of glutathione-HNE. This conjugate is further transported by a $76 \mathrm{kDa}$ ral-binding, ATP- 
dependent GTPase-activating protein (RLIP76) (Yang et al., 2003). As shown by the present data, GST activity using 4-HNE as a substrate was elevated significantly after $4 \mathrm{~h}$ of exposure of $F$. vesiculosus to NOD. This corresponds to the formation of 4-HNE via lipid peroxidation. Using CDNB as a substrate to measure GST activity, a constant elevation was detected which differs from the response detected with 4-HNE (the latter showing a decline of GST activity after $24 \mathrm{~h}$ of exposure). Taking into account that NOD, as shown by Beattie et al. (2003), can be conjugated to glutathione via a GST-catalysed reaction, this difference may be explained by the biotransformation activity of the GST system.

The increase in total antioxidative capacity is a further indication of NOD-promoted oxidative stress in F. vesiculosus. Significant elevation was observed after $6 \mathrm{~h}$ of exposure and resulted in an 11-fold activity increase when compared to control algae.

The activities of enzymes (SOD and CAT) involved in the detoxification of reactive oxygen species were significantly elevated after $4 \mathrm{~h}$ of exposure. Other studies have demonstrated that antioxidative enzymes in fucoids are a major factor in these brown algae to determine the resistance against oxidative stress (Collen \& Davison, 1999b). The observed activities of these enzymes in the present study are in the range observed in studies describing the development of oxidative stress during seasonal and thermal acclimation of $F$. vesiculosus (Collen \& Davison, 2001).

Comparing the reactions of plants and macroalgae to cyanobacterial toxins, the promotion of oxidative stress seems to be a common occurrence and possibly how cyanobacteria may be able to create their own ecological niche. Similar reactions were seen in the freshwater plant Ceratophyllum demersum after exposure to purified cyanobacterial toxins and a cell-free cyanobacterial crude extract (Pflugmacher, 2004).

The survival of plants under stress conditions is possible only if several antioxidants cooperate together with antioxidant enzymes. This work shows that exposure of $F$. vesiculosus to a NOD-containing solution induced the formation of reactive oxygen species as well as the 
antioxidative defence. We intend to carry out further studies to elaborate the ecological consequences of toxin uptake by marine macroalgae in the Baltic Sea environment.

\section{Acknowledgements}

We wish to thank the staff of the Tvärminne Zoological Station (University of Helsinki) for excellent assistance and the use of laboratory premises. This project has received funding through DAAD and the Academy of Finland (HK; grant numbers 208778 and 211645), which is gratefully acknowledged. Thanks also to K. A. Beattie for help with the manuscript.

\section{References}

Aebi, H. (1984). Catalase in vitro. Methods Enzymology, 105, 121-126.

Alin, P., Danielson, U.H., Mannervik, B. (1985). 4-hydroxyalk-2-enals are substrates for glutathione transferase. FEBS letters, 179, 267-270.

Beattie, K.A., Ressler, J., Wiegand, C., Krause, E., Codd, G.A., Steinberg, C.E.W., Pflugmacher, S. (2003). Comparative effects and metabolism of two microcystins and nodularin in the brine shrimp Artemia salina. Aquatic Toxicology 62, 219-226.

Botsoglou, N.A., Fletouris, D.J., Papageorgiou, G.E., Vassilopoulos, V.N., Mantis, A.J., Trakatellis, A.G. (1994). Rapid, sensitive, and specific thiobarbituric acid method for measuring lipid peroxidation in animal tissue, Food and Feedstuff Samples. Journal of Agriculture and Food Chemistry 42, 1931-1937.

Bradford, M. (1976). A rapid and sensitive method for the quantitation of microgram. Analytical Biochemistry 72, 248-254.

Carmichael, W.W., Eschedor, J.T., Patterson, G.M.L. Moore, R.E. (1988). Toxicity and partial structure of a hepatotoxic peptide produced by the cyanobacterium Nodularia spumigena Mertens emend. L575 from New Zealand. Applied Environmental Microbiology 54, 2257-2263. 
Collen, J., Davison, I.R. (1997). In vivo measurement of active oxygen production in the brown alga Fucus evanescens C.Ag. using $2^{\prime}, 7^{\prime}$-dichlorohydrofluorescin diacetate. Journal of Phycology 33, 787-793.

Collen, J., Davison, I.R. (1999a). Reactive oxygen production and damage in intertidal Fucus spp. (Phaeophyceae). Journal of Phycology 35, 54-61.

Collen, J., Davison, I.R. (1999b). Reactive oxygen metabolism in intertidal Fucus spp. (Phaeophyceae). Journal of Phycology 35, 62-69.

Collen, J., Davison, I.R. (2001). Seasonality and thermal acclimation of reactive oxygen metabolism in Fucus vesiculosus (Phaeophyceae). Journal of Phycology 37, 474-481.

Edler, L., Fernö, S., Lind, M. G., Lundberg, R., Nilsson, P. O. (1985). Mortality of dogs associated with a bloom of the cyanobacterium Nodularia spumigena in the Baltic Sea. Ophelia 24, 103-109.

Elmgren, R. (1989). Man's impact on the ecosystem of the Baltic Sea: energy flows today and at the turn of the century. Ambio 18, 326-332.

Esterbauer, H., Schaur, R.J., Zollner, H. (1991). Chemistry and biochemistry of 4hydroxynonenal, malonaldehyde and related aldehydes. Free Radical and Biological Medicine $11,81-128$.

Foyer, C.H., Halliwell, B. (1976). The presence of glutathione and glutathione reductase in chloroplasts: A proposed role in ascorbate acid metabolism. Planta 133, 21-25.

Habig, W. H., Pabst, M. J., and Jakoby, W. B. (1974). Glutathione S-transferase: the first enzymatic step in mercapturic acid formation. Journal of Biological Chemistry 249, 71307139.

Jonsson, P., Carman, R. (1994). Changes in deposition of organic matter and nutrients in the Baltic Sea during the twentieth century. Marine Pollution Bulletin 28, 417-426.

Kankaanpää, H.T., Sipiä, V.O., Kuparinen, J.S., Ott, J.L., Carmichael, W.W. (2001). Nodularin analyses and toxicity of Nodularia spumigena (Nostocales, Cyanobacteria) waterbloom in the western Gulf of Finland, Baltic Sea, in August 1999. Phycologia 40, 268274

Kankaanpää, H., Vuorinen, P., Sipiä, V., Keinänen, M. (2002). Acute effects of Nodularia spumigena and bio-accumulation of nodularin to brown trout (Salmo trutta L.) under laboratory conditions. Aquatic Toxicology 61, 155-168.

Kankaanpää, H., Turunen, A.-K., Karlsson, K., Bylund, G., Meriluoto, J., Sipiä, V. (2005). Heterogeneity of nodularin bioaccumulation in northern Baltic Sea flounders in 2002. Chemosphere 59, 1091-1097.

Karlson, K., Sipiä, V., Krause, E., Meriluoto, J., Pflugmacher, S. (2003). Mass spectrometric detection and quantification of nodularin-r in flounder livers. Environmental Toxicology 18, 284-288. 
Kononen, K., Sivonen, K., Lehtimäki, J. (1993). Toxicity of phytoplankton blooms in the Gulf of Finland and Gulf of Bothnia, Baltic Sea. Pp. 269-273 in: Smayda, T.J. and Shimizu, Y. (eds.) Toxic Phytoplankton Blooms in the Sea, Elsevier, Amsterdam.

Larsson, U., Elmgren, R., Wulff, F. (1985). Eutrophication and the Baltic Sea: Causes and consequences. Ambio 14, 9-14.

Lüning, K. (1990). Seaweeds, Their Environment, Biogeography and Ecophysiology. 527 pp, John Wiley \& Sons, New York.

Mann, K.H. (1982). Ecology of coastal waters. A systems approach. Blackwell, Oxford. 322 $\mathrm{pp}$

Mazur, H., Pliński, M. (2003). Nodularia spumigena blooms and the occurrence of hepatotoxin in the Gulf of Gdańsk. Oceanologia 45, 305-316.

Miller, N. J., Rice-Evans, C., Davies, M. J., Gopinathan, V., Milner, A. (1993). A novel method for measurement antioxidant capacity and application to monitoring the antioxidant status in premature neonates. Clinical-Science 84, 407-12.

Nehring, S. (1993). Mortality of dogs associated with a mass development of Nodularia spumigena (Cyanophyceae) in a brackish lake at the German North Sea coast. Journal of Plankton Research 15, 867-872.

Pflugmacher, S., Wiencke, C., Sandermann, H. (1999). Activity of phase I and phase II detoxication enzymes in Antarctic and Arctic macroalgae. Marine Environmental Research 48, 23-36.

Pflugmacher, S., 2004. Promotion of oxidative stress in $C$. demersum due to exposure to cyanobacterial toxin. Aquatic Toxicology 70, 169-178.

Sipiä, V. O., Kankaanpää, H. T., Flinkman, J., Lahti, K., Meriluoto, J. A. O. (2001a). Timedependent accumulation of cyanobacterial hepatotoxins in flounders (Platichthys flesus) and mussels (Mytilus edulis) from the northern Baltic Sea. Environmental Toxicology 16, 330336.

Sipiä, V., Kankaanpää, H., Lahti, K., Carmichael, W.W., Meriluoto, J. (2001b). Detection of nodularin in flounders and cod from the Baltic Sea. Environmental Toxicology 16, 121-126.

Sivonen, K., Kononen, K., Carmichael, W.W., Dahlem, A.M., Rinehart, K.L., Kiviranta, J., Niemelä, S.I. (1989). Occurrence of the hepatotoxic cyanobacterium Nodularia spumigena in the Baltic Sea and structure of the toxin. Applied Environmental Microbiology 55, 19901995.

Smith, I.K., Polle, A., Rennenberg, H. (1990). Glutathione. In: Alscher RG, Cumming JR (eds) Stress Responses in Plants. Adaptation and Acclimation Mechanisms. Wiley-Liss, New York pp 201-215.

Sun, Y., Oberley, L., Li, Y. (1988). A simple method for clinical assay of superoxide dismutase. Clinical Chemistry 34, 497-500. 


\section{ACCEPTED MANUSCRIPT}

Yang, Y., Sharma, R., Sharma, A., Awasthi, S., Awasthi, Y.C. (2003). Lipid peroxidation and cell cycle signalling: 4-hydroxynonenal, a key molecule in stress mediated signalling. Acta Biochimica Polonica 50, 319-336. 


\section{Legends}

\section{Figure 1}

Lipid peroxidation activity ( $\mathrm{pmol} \mathrm{mg}^{-1}$ protein) measured as the formation of malondialdehyde (MDA) and 4-hydroxynonenal (4-HNE) in Fucus vesiculosus after exposure to $1 \mu \mathrm{g} \mathrm{l}^{-1}$ nodularin in seawater.

\section{Figure 2}

The total antioxidative capacity (TAOC) ( $\mu \mathrm{mol} \mathrm{mg} \mathrm{m}^{-1}$ protein) in Fucus vesiculosus exposed to $1 \mu \mathrm{g}^{-1}$ nodularin in seawater and compared to non-exposed control algae.

\section{Figure 3}

The activity of superoxide dismutase (SOD) (nkat mg-1 protein) in Fucus vesiculosus exposed to $1 \mu \mathrm{g} \mathrm{l}^{-1}$ nodularin in seawater and compared to non-exposed control algae.

\section{Figure 4}

The activity of catalase (CAT) ( $\mu \mathrm{kat} \mathrm{mg}^{-1}$ protein) in Fucus vesiculosus exposed to $1 \mu \mathrm{g} \mathrm{l}^{-1}$ nodularin in seawater and compared to non-exposed control algae.

\section{Figure 5}

The activity of soluble glutathione S-transferase determined using the substrates 1-chloro-2,4dinitrobenzene (CDNB) (A) and 4-hydroxynonenal (4-HNE) (B) in Fucus vesiculosus after exposure to $1 \mu \mathrm{g} \mathrm{l}^{-1}$ nodularin in seawater and compared to non-exposed control algae. 


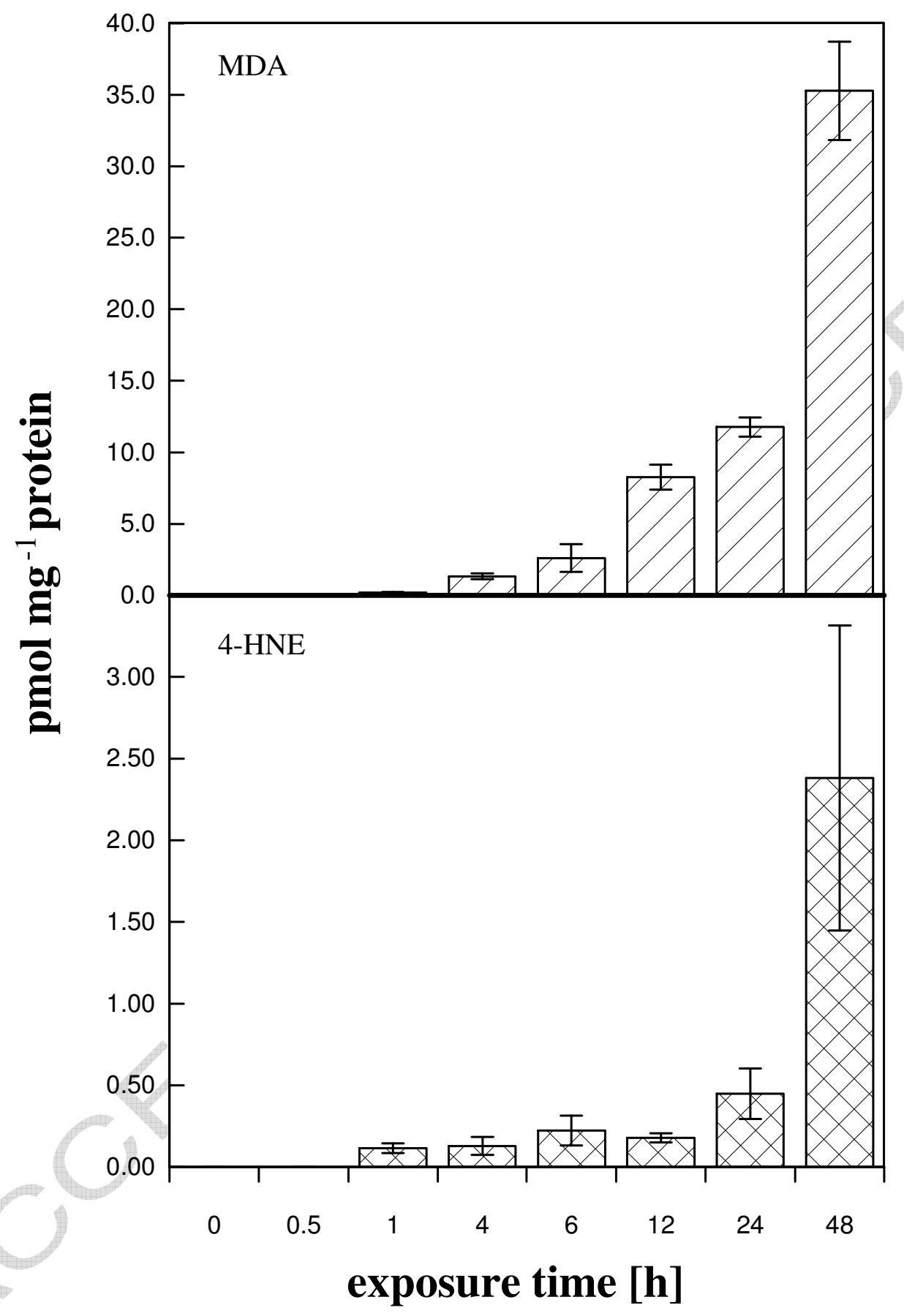

Fig. 1 


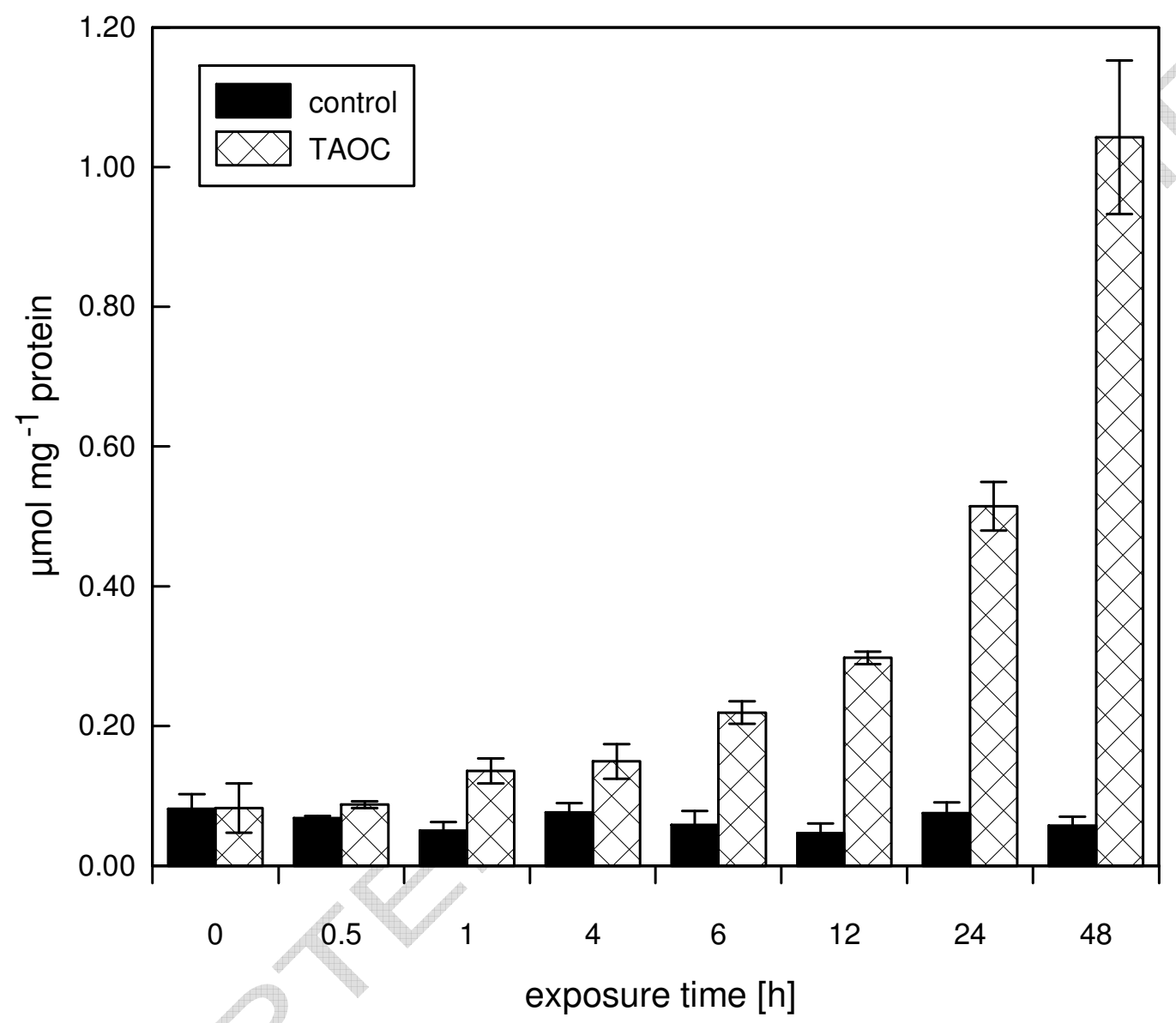

Fig. 2 


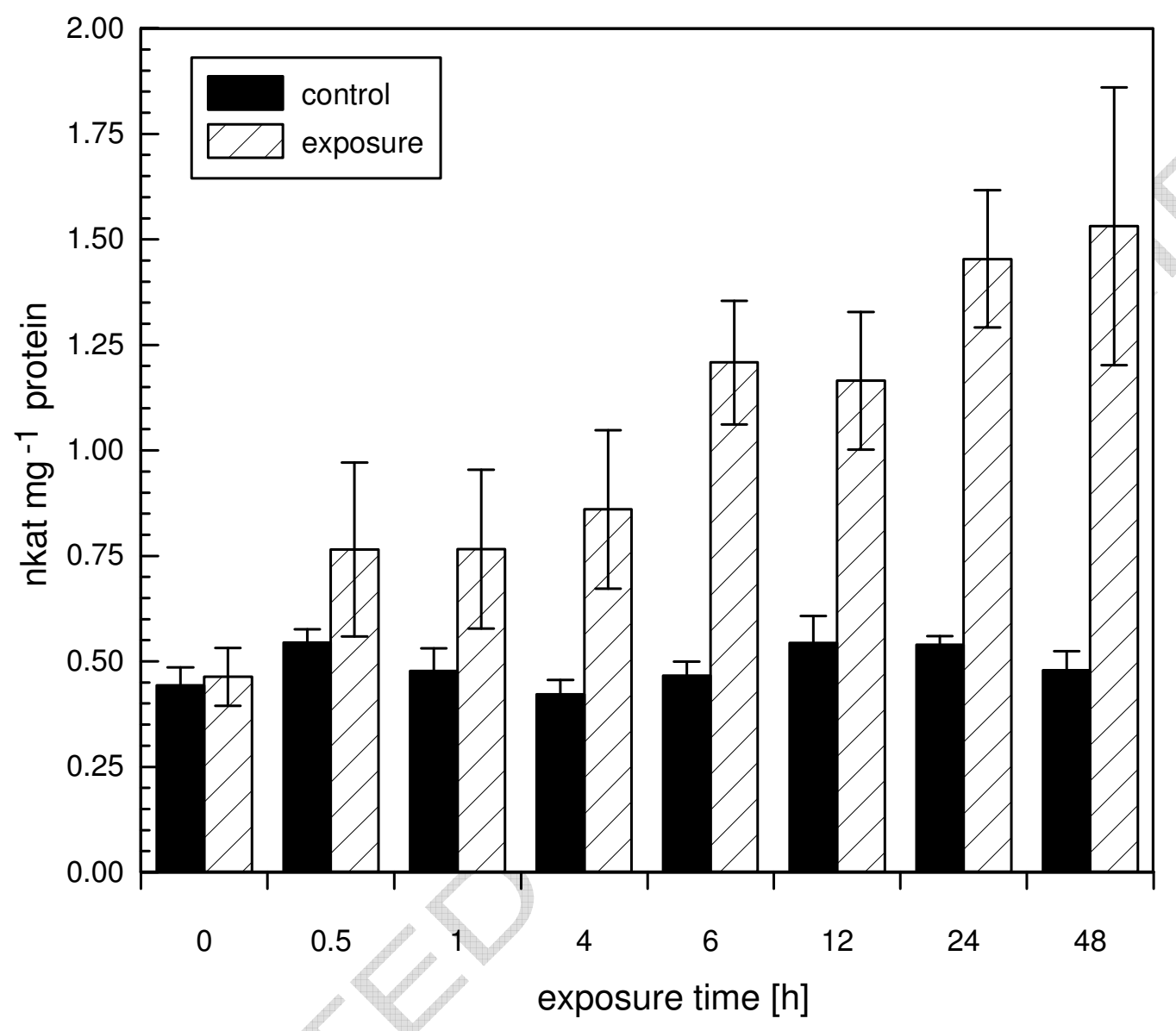

Fig. 3. 


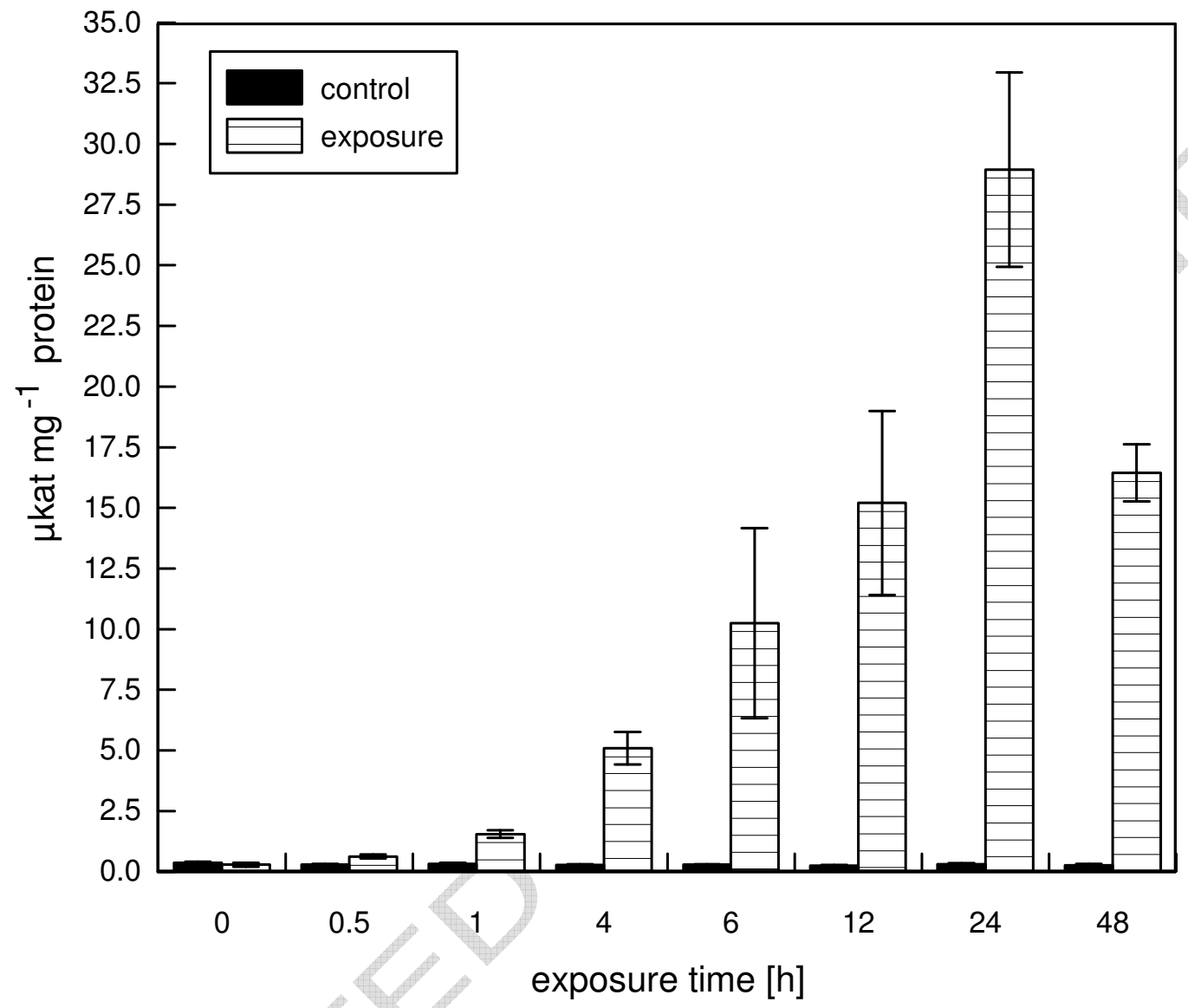

Fig. 4. 


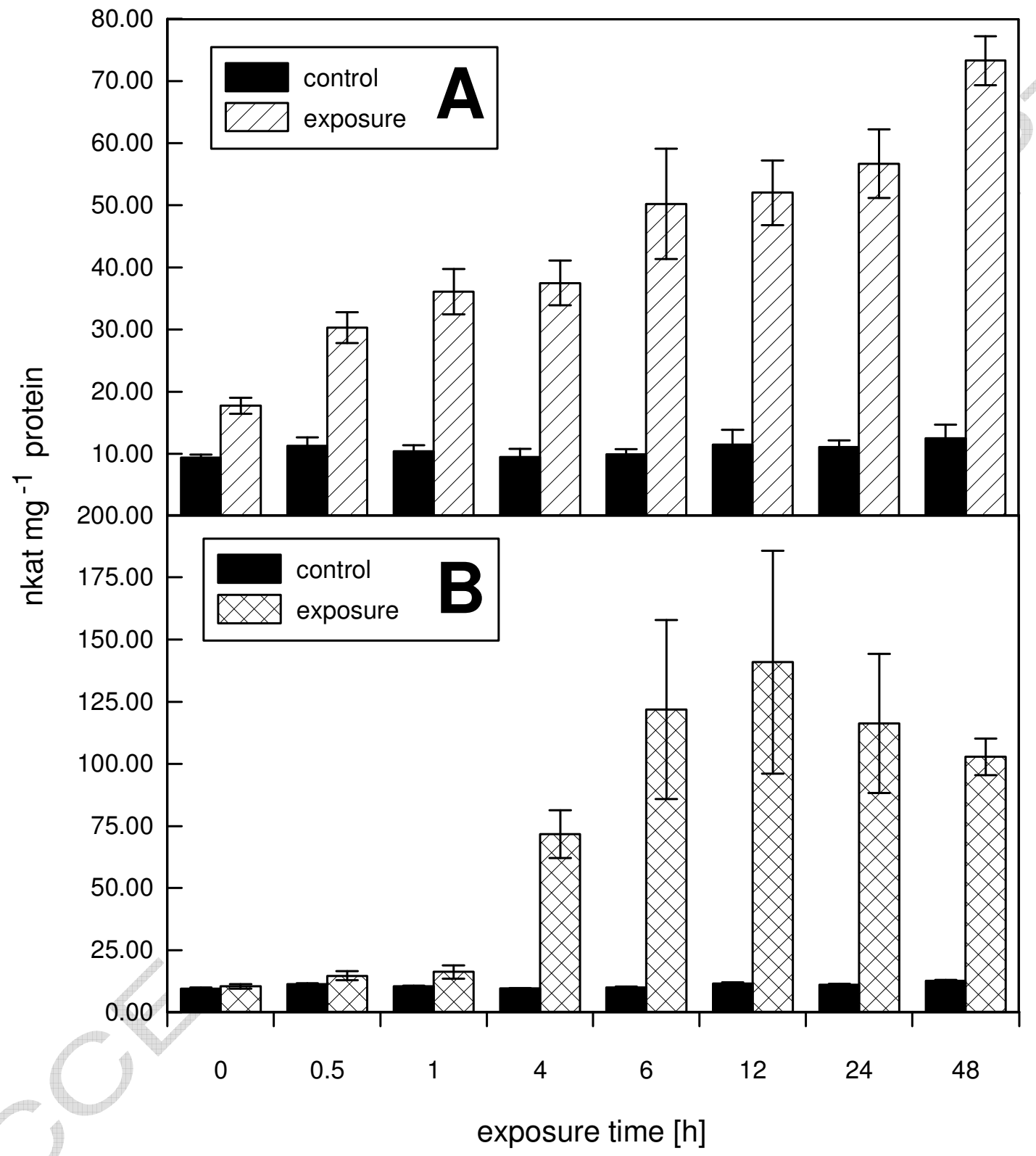

Fig. 5. 